\title{
Social weaknesses versus environmental conservation of Extractive Reserves in the Amazon
}

\author{
Fragilidades sociais versus conservação ambiental de Reservas Extrativistas na Amazônia
}

\author{
Josimar da Silva Freitas \\ Doutor em Desenvolvimento Socioambiental pelo NAEA/UFPA, Brasil \\ Josimarfreitas55@gmail.com \\ Luciano Félix Florit \\ Programa de Pós-Graduação em Desenvolvimento Regional \\ Universidade Regional de Blumenau, Brasil \\ lucianoflorit@gmail.com \\ Milton Cordeiro Farias Filho \\ Doutor em Desenvolvimento Socioambiental pelo NAEA/UFPA, Brasil \\ mcffarias@gmail.com
}

Alfredo Kingo Oyama Homma

Pesquisador da Embrapa Amazônia Oriental e da Universidade do Estado do Pará, Brasil

Alfredo.homma@embrapa.br

\begin{abstract}
Extractive Reserves (EXREs) in the Amazon were created to improve the living conditions of its inhabitants and protect natural resources. Seeking to observe this reality, this study aimed to evaluate social and productive policies from the perspective of socio-environmental sustainability of two EXREs from the Brazilian Amazon. Data and information were generated through observations, interviews, and a questionnaire with 150 residents of 29 communities of the EXREs Alto Juruá (Acre) and Rio Ouro Preto (Rondônia) in the Western Brazilian Amazon. The results indicate that the distance between social, economic and forest protection policies led the EXREs to decline. The conclusion is that these areas' sustainability depends on social policies associated with economic, ecological, and partnership policies that value environmental resources and ensure the inhabitants' minimum living conditions.
\end{abstract}

Keywords: Social politics, Productive activities, Extractive Reserves.

\section{Resumo}

As Reservas Extrativistas (RESEXs) na Amazônia foram criadas visando melhorar as condições de vida de seus habitantes e proteger os recursos naturais. Buscando observar esta realidade, este estudo teve como objetivo avaliar as políticas sociais e produtivas na perspectiva da sustentabilidade socioambiental de duas RESEXs da Amazônia brasileira. Os dados e informações foram gerados por meio de observações, entrevistas e uso de questionário com 150 moradores de 29 comunidades das RESEXs Alto Juruá (Acre) e Rio Ouro Preto (Rondônia) localizadas na Amazônia Ocidental brasileira. Os resultados indicam que o distanciamento entre políticas sociais, econômicas e políticas de proteção florestal conduziu as RESEXs ao declínio. A conclusão é que a sustentabilidade dessas áreas depende de políticas sociais associadas às políticas econômicas, ecológicas e parcerias que valorizem os recursos ambientais e garantam a manutenção de condições de vida dos habitantes.

Palavras-chave: Políticas sociais, Atividades produtivas, Reservas Extrativistas. 


\section{INTRODUCTION}

The Amazon basin is home to the largest tropical forest in the world (BLANCOGUTIÉRREZ et al., 2020), stockings globally significant carbon (GUIMBERTEAU et al., 2017), provides ecosystem and policy services aimed at forest protection (MENEZES, 2020), and ensures livelihoods for traditional peoples and communities (KAUANO et al., 2020). In this context, environment, ecology, Indians, traditional communities, forest, oxygen, water, biodiversity, conservation and preservation are terminologies that represent the Amazon reality (AMARAL FILHO, 2016).

The Amazon is at the forefront of global controversies over climate change, economic development and environmental justice (IORIS, 2020). The relationship between environmental conservation and development in the Amazon region has been the analysis object since the first studies on colonization in the region (ARAGÓN, 2020). The Amazon has become a globally known region as xenophobia grows, violence and terrorism increase, political conflicts spread, and environmental disasters and unsustainable exploitation intensify (ARAGÓN, 2017).

In an attempt to reduce these problems, the Brasilian State created Conservation Units (CUs), which are areas legally constituted by the State to reduce deforestation and protect environmental resources. CUs have been established to conserve tropical forests (WEISSE; NAUGHTONTREVES, 2016), decrease change in land cover (BERESFORD et al., 2013), minimize disturbances to archaeological monuments (SILVA; FRAXE; SILVA, 2015), protect natural resources and maintain ecological balance (SONG et al., 2017), against regional and global climate change (NOGUEIRA et al., 2018).

The UCs are divided into two groups, five of which are for integral protection and seven for sustainable use. Our focus is on the second group, specifically Extractive Reserves (EXREs), which are public areas that authorize traditional communities to develop sustainable, productive activities for subsistence purposes. The creation of EXREs was based on the claims of rubber tappers protesting against deforestation and pasture expansion in the State of Acre (ALLEGRETTI, 1989), plant and animal extractive defence (ALLEGRETTI, 1992), and protection of the Amazon biome against rampant exploitation in a predatory way (BARBOSA; MORET, 2015).

Throughout their history, EXREs have undergone experiences to improve the inhabitants' living conditions and the conservation of environmental resources. However, the EXREs do not present a balance between conservation and socio-economic development (FREITAS et al., 2020), due to the imposition of a conservation state logic that restricts traditional practices that make it impossible to improve the living conditions of the inhabitants (ANAYA et al., 2019). The difficulties of an alliance between conservation and development (FARIAS et al., 2018) involve discrepancies 
in resources, interests and power (CANTO et al., 2020), in a context resized by economic forces versus conservation of natural resources (AMIN, 2015).

Even with the creation of EXREs, it is observed that social and productive policies do not achieve results that meet the needs of families and forest protection in EXREs. This panorama justifies the research, whose objective is to evaluate social and productive policies from the perspective of socio-environmental sustainability of two EXREs in the Brazilian Amazon. More specifically, social policies of education and health have always been on the agenda of priorities of the inhabitants and the productive activities of extractivism, agriculture and animal husbandry. Furthermore, initiatives to encourage and invest in these policies and collaborate with social capital and community well-being can reverse the migratory flow of families to nearby urban centres.

This article is organized into four sections. First, we present the material and methods (research subjects, areas of study, data collection and analysis). Second, we evidenced the results and their respective analyses. Third, we discuss and validate the data based on the conceptual model. Fourth, we show the conclusions briefly.

\section{MATERIAL AND METHODS}

\subsection{Research subject}

The study was carried out in two EXREs: Alto Juruá and Rio Ouro Preto. The first was founded on January 23, 1990, through Decree 98.863, with 537.946 hectares (ICMBio, 2020). EXREs Alto Juruá is located in the municipality of Marechal Thaumaturgo, State of Acre, between the respective geographical coordinates: $0845^{\prime}$ and $0945^{\prime}$ 'south latitude and $72^{\circ} 00$ and $73^{\circ} 00^{\prime}$ ' longitude to the west (Figure 1). 


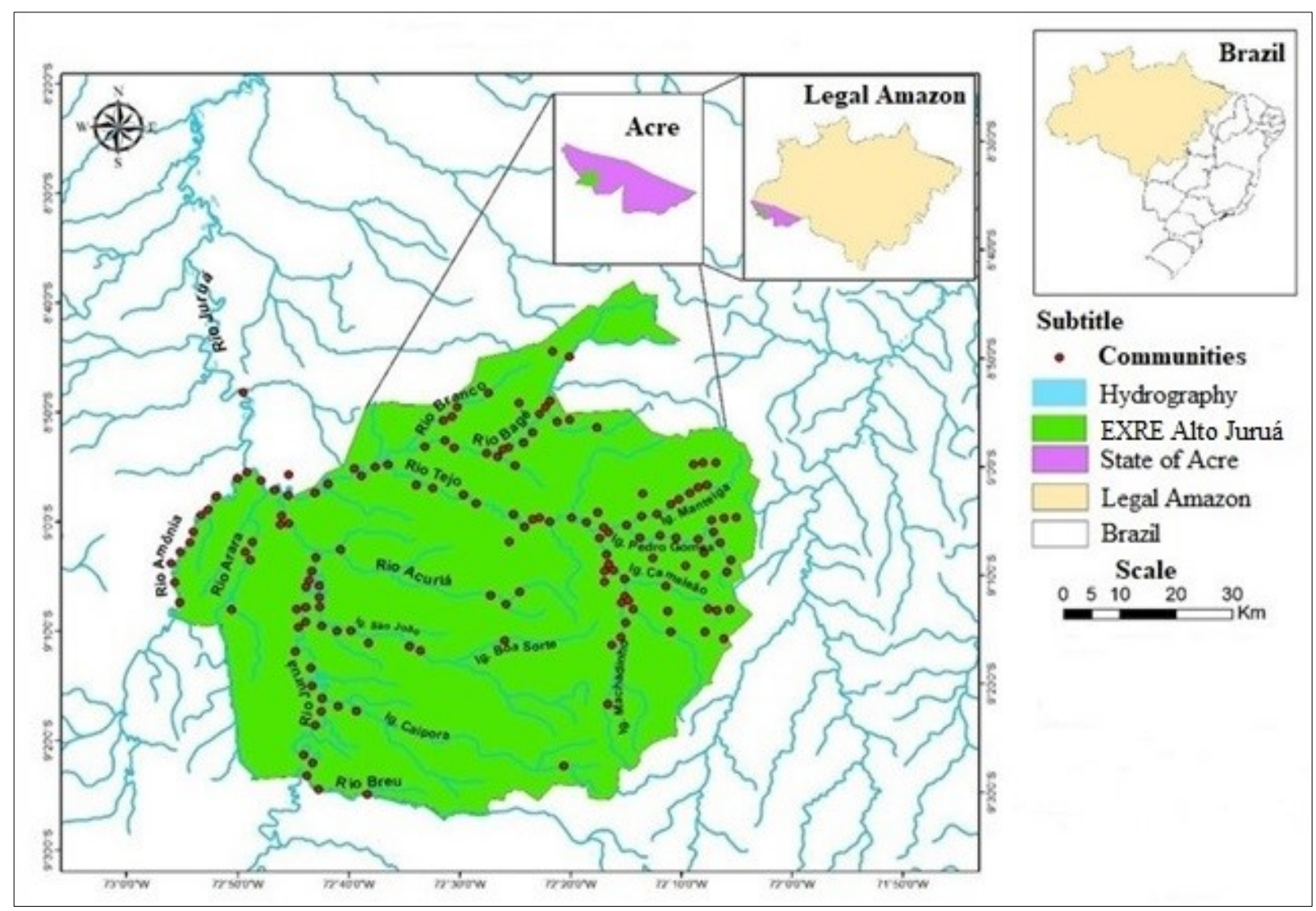

Figure 1 - Map of the EXRE Alto Juruá and subdivisions. Source: The authors.

In this EXRE there are 4.170 people, organized into 1.042 families and distributed in 80 communities, on the banks of the main rivers: Juruá, Tejo, Amônia, Breu and Manteiga (IBGE, 2010). They are people of simple origin who hunt, fish, work in the swidden, raise animals, collect vegetable oils and other fresh products. The subsistence economy comes from the income of cassava flour, tobacco and cattle raising.

In this sense, EXRE Rio Ouro Preto was created on March 13, 1990, through Decree 99.166, with 204.631 hectares (ICMBio, 2020). EXRE is contained in Guajará-Mirim and Nova Mamoré, State of Rondônia, punctually in the following geographical coordinates: $64^{\circ} 18^{\prime}$ and $65^{\circ} 16^{\prime}$ west and $10^{\circ} 35^{\prime}$ and $11^{\circ} 03^{\prime}$ South (Figure 2). 


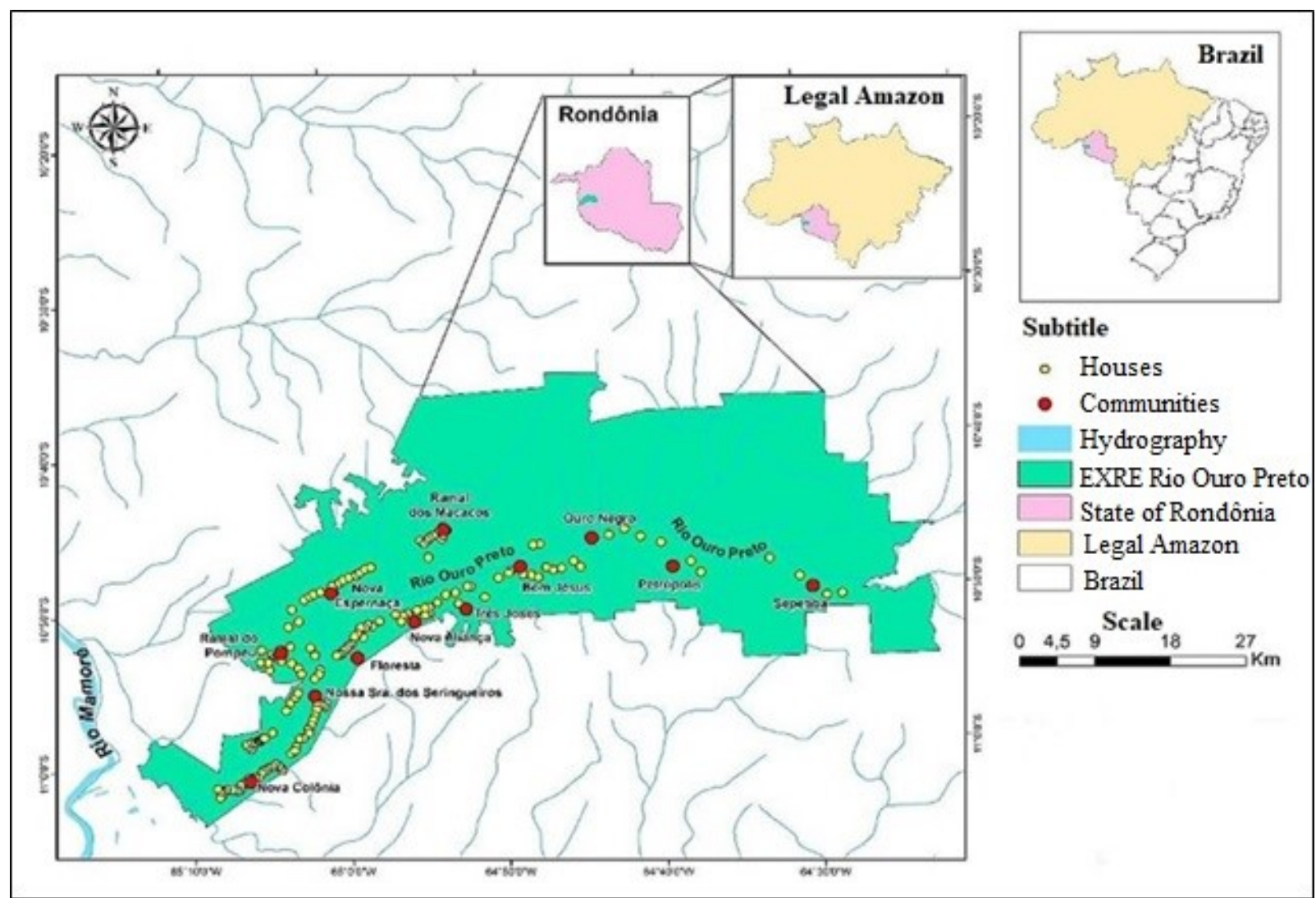

Figure 2 - Map of the EXRE Rio Ouro Preto and subdivisions.

Source: The authors.

In this EXRE live 699 inhabitants, corresponding to 172 families spread in 12 communities, on the banks of back roads and the Rio Ouro Preto (IBGE, 2010). To ensure subsistence, people daily carry out combined productive activities of cattle raising, extractivism of Brazil nuts and cassava flour, among the main ones.

In the two EXRE, there is no "pure" figure of the extractive, farmer, hunter and fisherman because all workers perform the set of functions. These practices occur because the culture passed on by their descendants, and the need to increase income and provide support to families.

\subsection{Study design, data collection and analysis}

We interviewed 150 people responsible for a residential unit, 99 in EXRE Alto Juruá and 51 at EXREs Rio Ouro Preto, located in the states of Acre and Rondônia. A semi-open questionnaire was used with 19 questions about health and education situation, productive activities, interrelations of inhabitants with natural resources and some strategic possibilities that cooperate with environmental, economic and social improvements of EXREs.

Data were collected during two months, between February and April of 2019. At EXRE Alto Juruá, 20 communities were studied, namely: Tartaruga I, Tartaruga II, Pau Brasil, Foz do Piranha, Arenal, Fazenda Cachoeira, Belforte, Adão e Eva, São Luiz, Bandeirante I, Bandeirante II, Pedra 
Alta, São José, Bethânia, Tapuã, Acuriá I, Acuriá II, Jardim da Palma, Matrinchã and Foz do Tejo. In the EXRE Rio Ouro Preto nine communities were studied, they are: Alfredo Carneiro, Seringueiro, Pompeu, Nova Aliança, Bom Jesus, Três José, Ouro Preto, Floresta and Nossa Senhora do Seringueiro.

A qualitative approach was performed through informal conversations, some observations of daily life with the use of a voice recorder. Survey participants have differences in gender, religion, race, economic level, and social class. The knowledge and experiences of these participants were taken into account, and the selected informant was responsible for each residence.

The content of the information collected in the qualitative approach was related to quantitative data collected with a questionnaire. For the analyses, descriptive frequency statistics and tests of mean, median, moda, standard deviation, variance and correlation were used. In addition, maps were elaborated based on vector, matrix, drainage, locality and hydrography data analyses. The sources for the maps were the National Water Agency (ANA), the Brazilian Institute of Geography and Statistics (IBGE), the National Institute of Space Research (INPE/PRODES) and the Management Plans.

The study makes an association between the variables of agrarian, environmental, economic, physiological, genetic, molecular, political, psychological, institutional and sociological knowledge. This procedure allowed advances in previous studies (FREITAS et al., 2020; FREITAS et al., 2017). In this way, three dimensions of public policies were studied - environmental (extractivism and deforestation reduction), productive (farm activities, animal husbandry) and social (education and health).

\section{RESULTS}

The Brazilian rural educational system faces problems that interfere with the improvement and quality of teaching and learning. In particular, in rural schools in the Northern Region, the biggest obstacles are related to the precarious conditions of the school physical environment, low supply of teachers, scarcity of snack and teaching materials. Although there is no single formula for measuring quality in education, Table 1 shows examples of qualitative indicators that serve as a parameter to understand some fundamental elements of basic education. In this logic, indicators cooperate with a way of thinking, organizing, measuring, acting, focusing, directing (DIZDAROGLU, 2017) and making decisions (PRETTY, 2008). 
Table 1: Qualitative parameters of quality of teaching of basic education.

\begin{tabular}{|c|c|c|c|}
\hline $\begin{array}{l}\text { Fundamental } \\
\text { Elements }\end{array}$ & $\begin{array}{l}\text { Indicator (1) } \\
\text { Sufficiency }\end{array}$ & $\begin{array}{c}\text { Indicator (2) } \\
\text { Quality }\end{array}$ & $\begin{array}{l}\text { Indicator (3) } \\
\text { Good Yield }\end{array}$ \\
\hline Internet & $\begin{array}{l}\text { School connected to the } \\
\text { internet? }\end{array}$ & $\begin{array}{l}\text { Does the connection allow } \\
\text { research fast? }\end{array}$ & $\begin{array}{l}\text { Students and teachers with } \\
\text { access? }\end{array}$ \\
\hline $\begin{array}{l}\text { Teaching } \\
\text { materials }\end{array}$ & $\begin{array}{l}\text { There are a Tv, computer, } \\
\text { overhead projector and } \\
\text { printed materials? }\end{array}$ & $\begin{array}{l}\text { The equipment is in good } \\
\text { condition and meets the } \\
\text { needs of students? }\end{array}$ & $\begin{array}{l}\text { Parents or guardians are } \\
\text { participating in the school } \\
\text { community? }\end{array}$ \\
\hline Library & $\begin{array}{l}\text { There is a library or a space } \\
\text { for reading? }\end{array}$ & $\begin{array}{l}\text { Does the library have an } \\
\text { organized acquis? }\end{array}$ & $\begin{array}{l}\text { Does the school community } \\
\text { have access to the acquis? }\end{array}$ \\
\hline $\begin{array}{c}\text { Structured } \\
\text { classroom with } \\
\text { air-conditioned }\end{array}$ & $\begin{array}{l}\text { Are classrooms sufficient for } \\
\text { students? }\end{array}$ & $\begin{array}{l}\text { Are classrooms airy and well } \\
\text { lit? }\end{array}$ & $\begin{array}{l}\text { Do the classrooms allow the } \\
\text { organization of furniture and } \\
\text { dynamic activities? }\end{array}$ \\
\hline $\begin{array}{l}\text { Space for the } \\
\text { practice } \\
\text { of sports }\end{array}$ & $\begin{array}{l}\text { There is space for the } \\
\text { teaching and practice of } \\
\text { sports? }\end{array}$ & $\begin{array}{l}\text { The space for teaching and } \\
\text { practice of sports meets the } \\
\text { needs of students? }\end{array}$ & $\begin{array}{l}\text { There is alternative space for } \\
\text { the dynamics of sports of } \\
\text { pupils, in the absence of } \\
\text { appropriate space? }\end{array}$ \\
\hline School Snacks & $\begin{array}{l}\text { Is it possible to prepare a } \\
\text { snack in their own school? }\end{array}$ & $\begin{array}{l}\text { The snacks offered are } \\
\text { balanced and nutritious? }\end{array}$ & $\begin{array}{l}\text { Do all have access to school } \\
\text { snacks? }\end{array}$ \\
\hline Teachers & $\begin{array}{l}\text { There is a structured } \\
\text { classroom for all teachers? }\end{array}$ & $\begin{array}{l}\text { Are teachers qualified and } \\
\text { well-paid? }\end{array}$ & $\begin{array}{l}\text { Does the offer meet the } \\
\text { demands of students? }\end{array}$ \\
\hline
\end{tabular}

Source: Adapted from indicators of quality in education, 2004.

Here, each of these dimensions consists of a group of indicators, which are evaluated by questions to be answered collectively, that is, the school community evaluates the quality of the school as each indicator, and concludes whether the situation is good, medium or bad (RIBEIRO; GUSMÃO, 2004). In the teaching units of the Alto Juruá and Rio Ouro Preto EXREs, the fundamental elements of basic education are similar to the aforementioned quality indicators. Table 2 shows the current human, technological, infrastructure and food conditions of EXREs.

Table 2: Reality of teaching units of EXREs Alto Juruá and Rio Ouro Preto.

\begin{tabular}{lccc}
\hline \multicolumn{1}{c}{ Situation of education } & Frequency & \%Valid & \% Accumulative \\
\hline $\begin{array}{l}\text { Features school with direction and teachers } \\
\begin{array}{l}\text { There is missing of school teachers, the internet, snack } \\
\text { and transportation to take students to schools }\end{array}\end{array}$ & 22 & 14.7 & 14.7 \\
There is a school, but the teachers miss classes & 3 & 2.0 & 90.7 \\
There is a school, but there are not students to start lessons & 2 & 1.3 & 96.7 \\
Lack of qualification of teachers & 2 & 1.3 & 99.3 \\
I don't know & 1 & 0.7 & 100.0 \\
Total & $\mathbf{1 5 0}$ & $\mathbf{1 0 0}$ & \\
\hline
\end{tabular}

Source: Survey data. 
The data confirm that the tiny investments of public institutions harm local students since there is a lack of teachers, the internet, school snack and transportation to take students to schools in the two EXREs. Education is the highest priority of parents and guardians in these areas. Respondents say that every effort is made to ensure that their children do not stay out of school. The most common, refers to the transfer of students from the communities of the EXREs to urban areas, being the continuation of elementary school I, elementary II and entry into high school the main migratory reasons.

This decision has social and economic costs because those responsible report the following changes: (1) the children start living with relatives in the urban environment, (2) buy or build a house near the teaching units in the urban perimeter, (3) and in some cases, the wife accompanies the children, while the husband continues in the EXRE to support them in the urban area. To overcome this situation, the interviewees stated that the State should observe the following needs more closely (Figure 3)

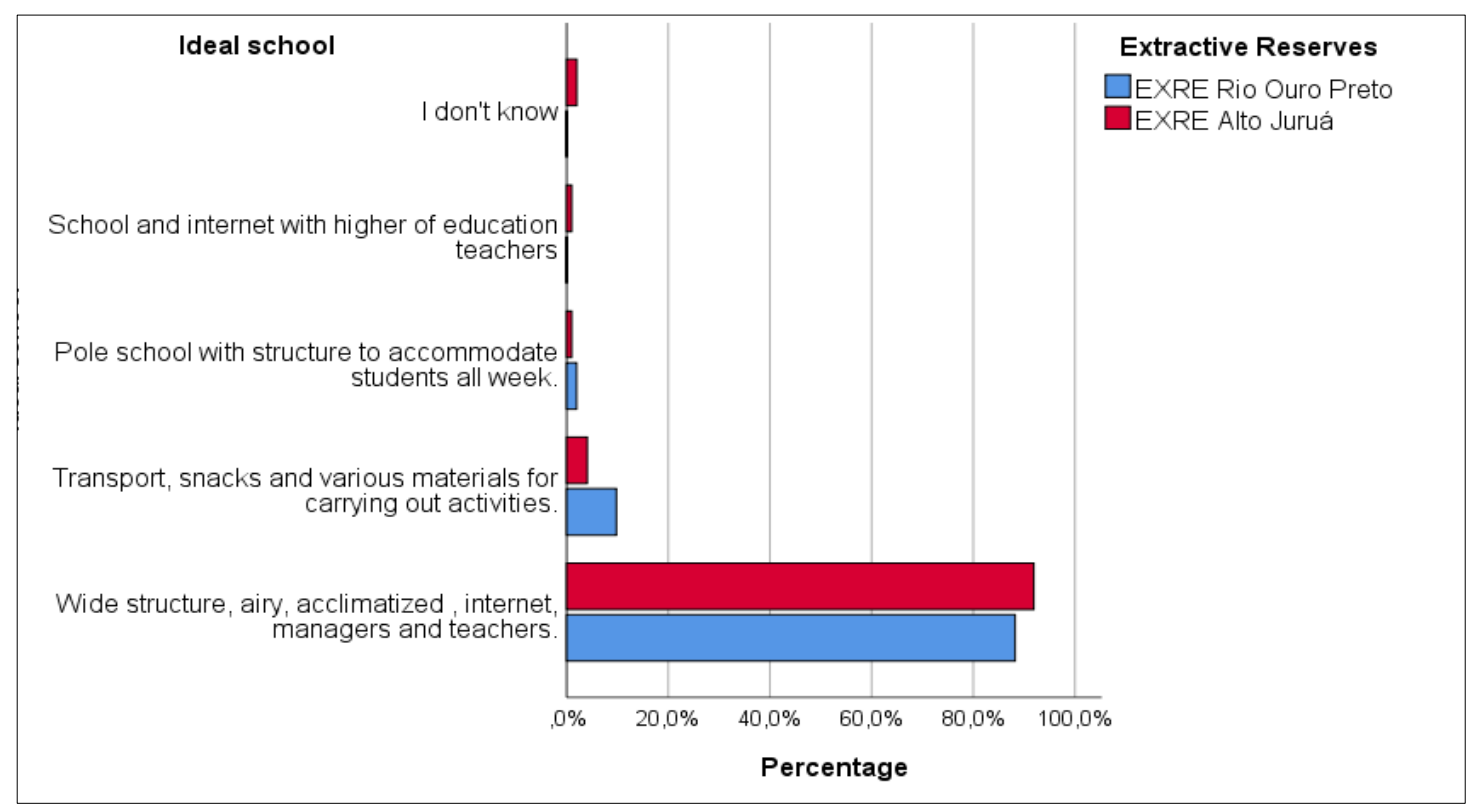

Figure 3 - Needs perceived to be improved in educational units.

Source: Survey data.

The leaders and students of the EXREs Alto Juruá and Rio Ouro Preto would be satisfied in their communities if the State offered through its teaching units the respective benefits: wide structure, airy, air-conditioned, internet, managers and teachers. This initiative would ensure the following advantages: (1) permanence of children with those responsible in their communities of origin, (2) cooperation in extractive, agricultural and animal production productive activities, (3) integration and family settlement in the communities of EXREs.

These suggestions are related to parents' concern about the future of their children, since the information that reaches family homes through televisions, radio and relatives in urban areas justify 
that if such benefits are not offered, the students' quality of learning will remain weak. That is, students are less likely to compete with students who receive structure greater than the one mentioned.

Health is another public policy that in Brazil is constitutionally defined as a right of all and duty of the State. It aims to reduce the risk of diseases and to carry out low and high complexity treatments (Art. 196 of the CF). However, the offer of the physical structure and public health professionals in rural areas may not be demographically proportional to the urban environment. For example, in the EXREs Alto Juruá and Rio Ouro Preto, access to essential health services presents vulnerabilities due to the lack and/or a low number of professionals and health units (Table 3).

Table 3: Health care conditions in EXREs Alto Juruá and Rio Ouro Preto.

\begin{tabular}{lccc}
\hline \multicolumn{1}{c}{ Health conditions } & Frequency & \%Valid & \% Accumulative \\
\hline There is a health clinic and visit from the Community health agent & 30 & 20.0 & 20.0 \\
There is not a health unit, only in the urban perimeter & 116 & 77.3 & 97.3 \\
1 to 2 times a year health professionals carry out consultations & 1 & 0.7 & 98.0 \\
We do not have fixed and mobile health care & 2 & 1.3 & 99.3 \\
I don't know & 1 & 0.7 & 100.0 \\
Total & $\mathbf{1 5 0}$ & $\mathbf{1 0 0}$ &
\end{tabular}

Source: Survey data.

Based on the information provided by the majority of the interviewees, in the EXREs, there is no health unit, and when they get sick, they go to urban centres looking for treatment. And in some cases, when the health unit is installed in the community, professionals and medicines are lacking, leaving only the Community Health Agent (CHA) with sodium hypochlorite. This situation leaves the inhabitants unassisted, while increasing economic costs, stresses and deaths caused by serious diseases and high complexity accidents.

The communities of the EXREs are located at the banks of rivers, streams and back roads, as well as are distant from urban centres. In severe cases, such as an accident at work, snake bite, or some tropical disease, the probability of a patient to arrive alive in the hospital becomes remote. Figure 4 shows the needs and desires of the inhabitants to alleviate the social and community strain of public health in these areas. 


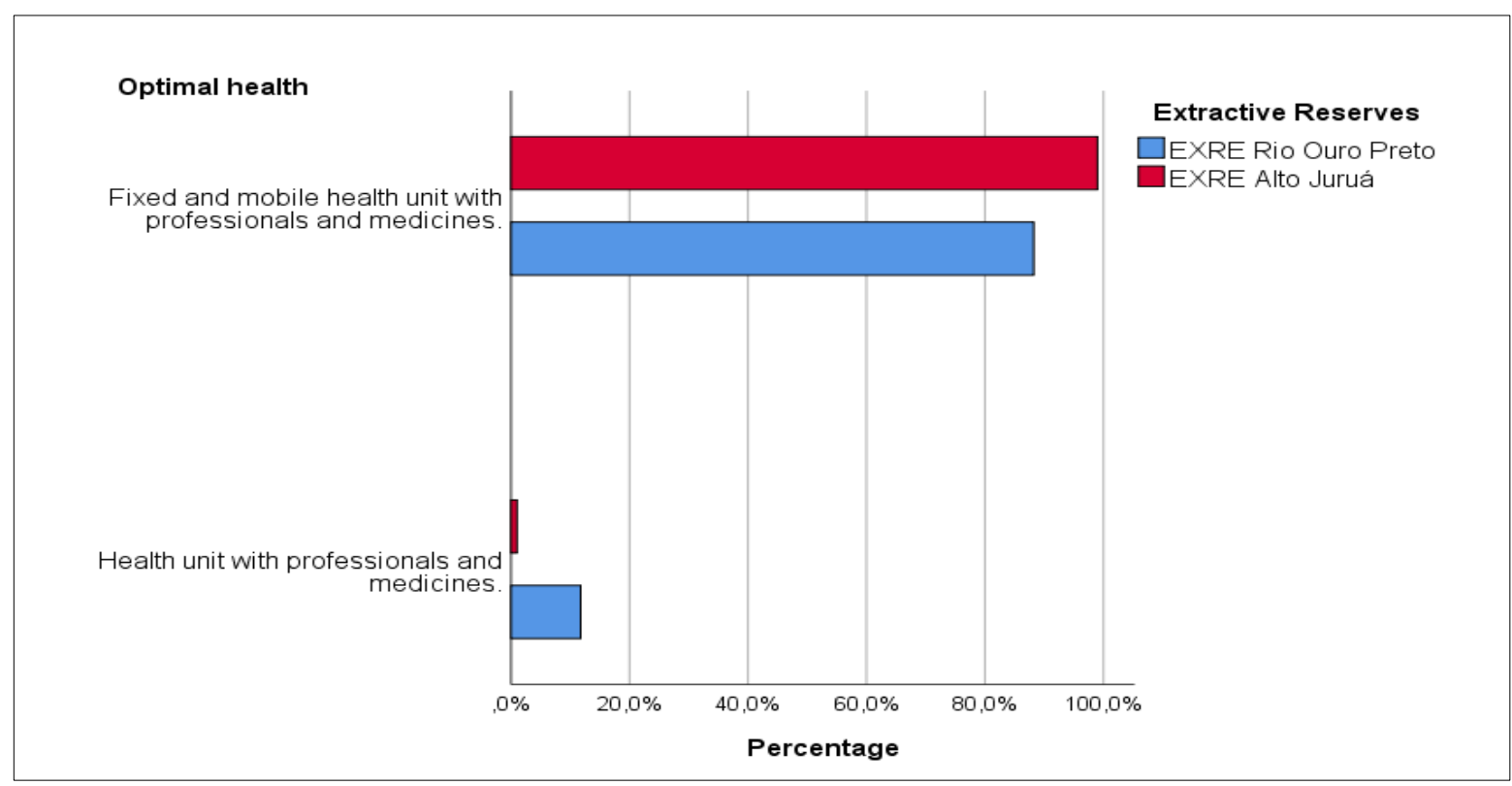

Figure 4 - Propositions that establishes the minimum of health service Source: Survey data

The level of complexity and challenges reaches its limit in the EXREs because the interviewees ensured that to improve health care, the State must provide fixed and mobile health units with professionals and medicines. The suggestions pointed out by the residents are essential to survival, and are not recommended by the Ministry of Health $(\mathrm{MH})$ currently. The possible implementation would contribute to the regular functioning of services, the permanence of residents in their communities and a considerable decrease in the risk of deaths. In addition, coronavirus (COVID-19) arrived in the forests of the EXREs. Some inhabitants move from EXREs to urban centres to buy industrialized food and withdraw retirement money and emergency aid, contracted the coronavirus and transmitted it to other residents who remained in the EXREs.

In terms of productive activities, the extraction of chestnut, rubber and vegetable oils continues to face many challenges in the face of the competitiveness of other competing non-timber products (Table 3) that provide higher income. Most producers working with extractivism are based on the seasonal shortage of chestnut trees, which occurs annually.

Table 3: Rubber extractivism, vegetable oils and chestnut in EXREs Alto Juruá and Rio Ouro Preto.

\begin{tabular}{lccc}
\hline Extractivism & Frequency & \% Valid & \% Accumulative \\
\hline There is no production of chestnut trees & 21 & 14.0 & 14 \\
\hline Easy selling & 40 & 26.7 & 40.7 \\
\hline The job only with chestnuts & 87 & 58.0 & 98.7 \\
\hline I do not work & 2 & 1,3 & 100 \\
\hline Total & $\mathbf{1 5 0}$ & $\mathbf{1 0 0}$ &
\end{tabular}


The data refer to the interviewees' opinion regarding the situation of the extractive economy. For them, the low supply and productivity of chestnut trees compromise the annual household income. For example, at EXRE Alto Juruá the native chestnut trees, the production and harvest are insufficient to feed the families. The fruit of the chestnut by the fact that it takes more than a year for its formation, a good crop year is followed by a fall the following year and vice versa. At EXRE Rio Ouro Preto, despite the fluctuations in annual quantity, families claim that the collection serves to complement income from other activities (agriculture and animal husbandry). The seasonal period of the crop of chestnuts in the Amazon occurs between December and March, and market values fluctuate according to the amount of annual supply.

Considering the context, those who maintain that they work only with chestnut trees and sell easy belong to EXRE Rio Ouro Preto, and those who explain that they do not work with chestnut because there is no enough production refer to the inhabitants of EXRE Alto Juruá. Regarding the extraction of rubber and vegetable oils, the study participants stated that in the past, the products reached considerable economic value; however, after the collapse of rubber, there were no incentives for productive maintenance. In addition, the time spent with the labour of the two activities is inversely proportional to the value obtained in other products. Thus, these experiences motivate new strategies and investments to be sophisticated and to enhance extractive activities (Figure 5).

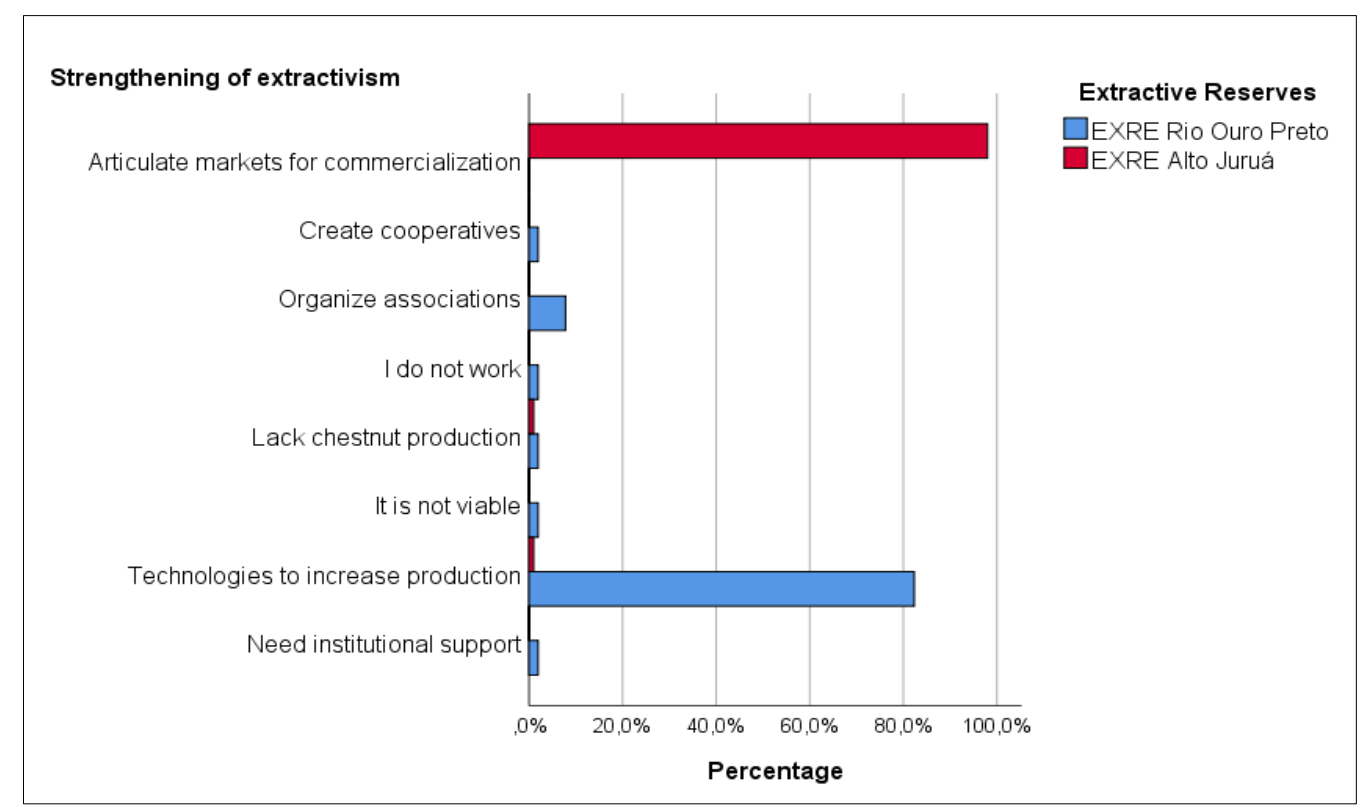

Figure 5: Strengthening the extractivism of rubber, vegetable oils and chesnut. Source: Survey data.

The interviewees suggest strengthening extractivism (rubber and vegetable oils) by articulating markets for commercialization in EXRE Alto Juruá, and technologies to increase production, especially Brazil nuts at EXRE Rio Ouro Preto. In these EXREs, some food products do not undergo commercialization because they are linked to local culture and low productive supply. 
For example, the resources that nature offers have indispensable utility for survival, especially medicinal plants (94\%), which serve as remedies for curing diseases and preparing teas. Products such as country chicken and eggs (3,3\%), pigs, milk and beef $(2 \%)$ marketing due to low production.

In addition, the activities of extractivism, agriculture and animal husbandry (especially cattle) take place in a combined or parallel way. At EXRE Alto Juruá, with the predominance of agriculture and livestock, extractive activity became complementary. While in EXRE Rio Ouro Preto livestock and agriculture have significant production, commercialization and market value, the extractivism of the chestnut continues to decline.

For the interviewees, cattle contribute to subsistence (74.7\%), supply various needs $(2.7 \%)$, can be combined with agriculture and forest $(1.3 \%)$, less laborious $(0.7 \%)$; however, it presents a conflict with environmental conservation (3.3\%). In an attempt to ease wear, residents point out some propositions aimed at balancing conservation and development (Figure 6).

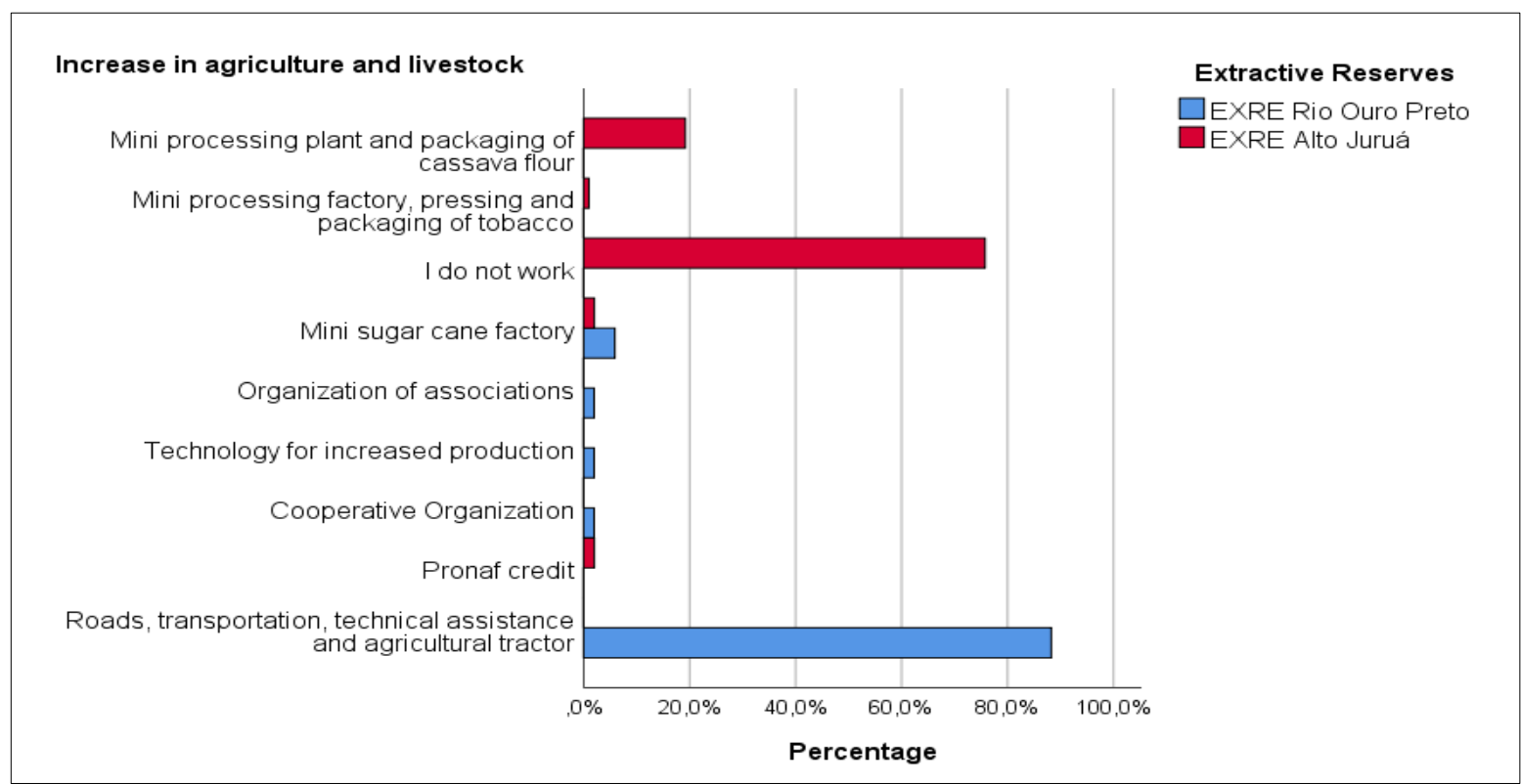

Figure 6: Importance of agriculture and livestock to the livelihoods of the inhabitants. Source: Survey data.

The interviewees justified that agriculture and cattle fulfil socio-economic functions since it meets basic needs of food, medicines, children at school, purchases and payments of bills, among other expenses. For them, the implementation of mini processing plant and packaging of cassava flour, mini processing plant, pressing and packaging of tobacco would be two useful projects that would improve the lives of the inhabitants of EXRE Alto Juruá. At EXRE Rio Ouro Preto, the improvement of road roads, transport, technical assistance and agricultural tractors would be essential projects just would modify the scenario of economic unsustainability. 
Notably, socio-economic development projects are not present in government planning, certainly due to the different interests between the State. In other words, while families expect projects that improve living conditions with less environmental impact, the State is implementing projects that just maintain natural resources as a priority.

In this sense, the interviewees stated that the focus of the "Government" is directed to forest conservation (94.7\%) and not the improvement of our lives $(0.7 \%)$, because public policies contribute little to human subsistence $(3.3 \%)$, or by ineffectiveness and distancing from conservation and development (0.7\%). Important to emphasize, that these families do not seek wealth, only sustainable projects that value them and ensure survival (Figure 7).

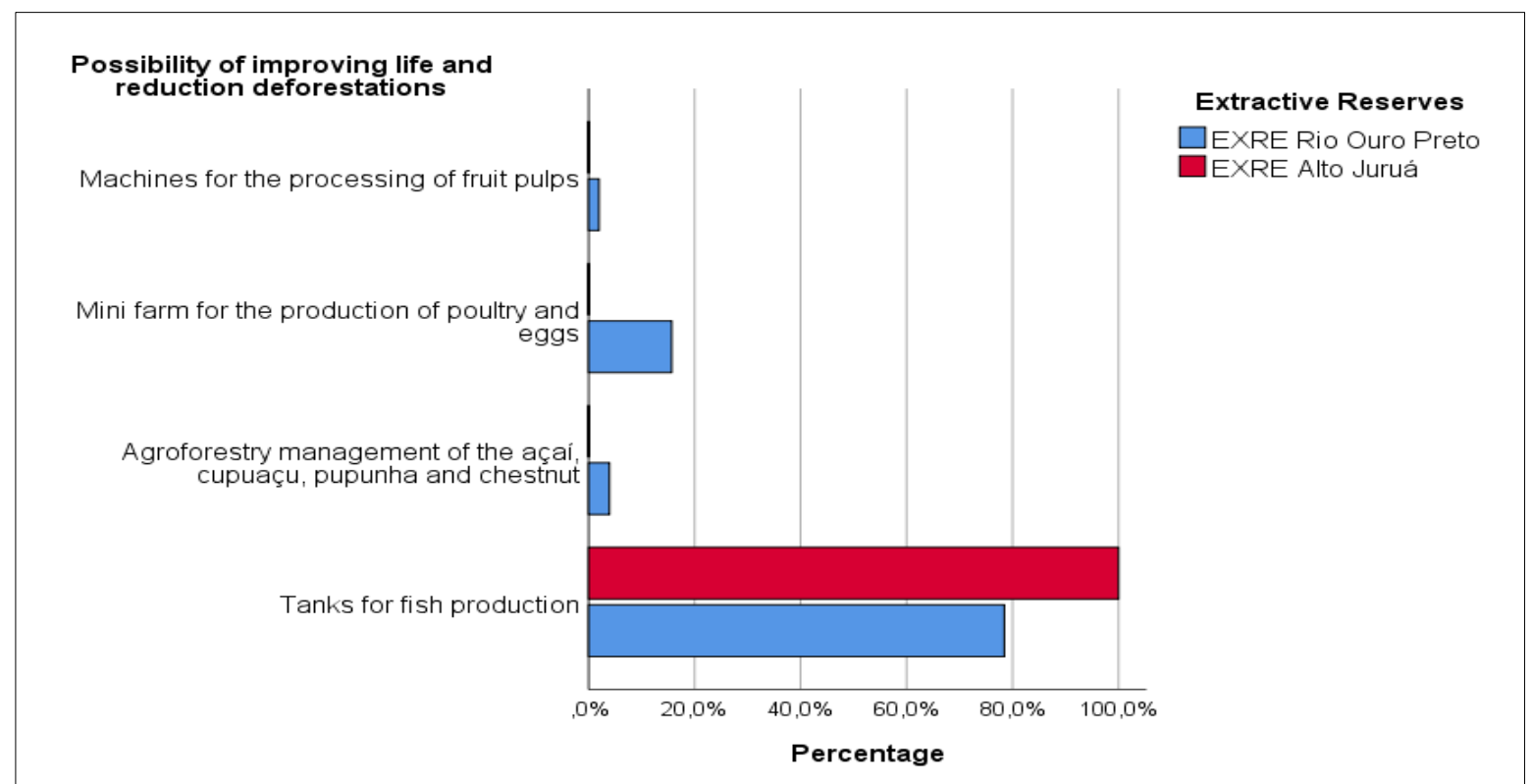

Figure 7: Improvement in the living conditions of the inhabitants with minimal impact on environmental resources. Source: Survey data.

Based on the interviewees' testimony, for the two EXREs, the best option is the construction of excavated tanks for fish production. The reasons refer to the scarcity of fish from rivers, occupies little space, does not degrade and/or pollutes the environment, has market potential and is extremely healthy. EXRE Rio Ouro Preto participants add that economic and structural investments collaborate with the implementation of mini-farms for the production of poultry and eggs; machines for processing fruit pulps; and agroforestry management of açai, cupuaçu, pupunha and chestnut.

These projects align with the potential for local socio-economic development. It is being requested by the residents themselves, looking to allow subsistence and commercialization of the surplus, insignificantly impact the environment (digging of tanks), improve the lives and happiness of the inhabitants, and keep families in their homes in the communities of the EXREs. 


\section{DISCUSSION}

The EXREs Alto Juruá and Rio Ouro Preto demonstrate vulnerabilities in the social systems of education, health and part of the productive system of extraction of chestnut, rubber and vegetable oils. Despite the difficulties in agriculture and cattle breeding, these are the two productive activities with the greatest economic potential — the first, very old, present diversity, availability and sale of products all year round. And the second is recognized for the facilities of creation, sale and good price, but with greater impact on the forest.

Agriculture and livestock activities ensure the minimum need necessary for the survival of families. Although conflicting, for the purposes of EXREs, these two productive activities are present and have been revealed by recent literature. At EXRE Chico Mendes, the combination is essential, because more than half of families have an average income below one minimum wage, and about $15 \%$ of them with income that puts them below the poverty line (MACIEL et al., 2018). Small-scale agriculture offers valuable contributions to local development to different social actors (WALTER et $a l ., 2016)$, and is therefore economically viable to the inhabitants (KLIMAS, 2012).

It has been a long time since productive activities have lived with a high degree of impact on the forest, as well as others considered sustainable. For many families, cattle and buffalo farming appears as a possibility for solving financial problems (MACIEL et al., 2010); means of subsistence, source of animal protein and means of transport for agricultural products (SPÍNOLA, 2019). With cattle, "money arrives faster" (KRÖGER, 2019), can be marketed with a cash payment (MACIEL; ALMEIDA; MENEZES, 2018), guarantee income (SIVIERO; TEIXEIRA; SANTOS, 2019), and gains considerable spaces economically the small production (CAVALCANTI; BATISTA; SOUZA, 2018).

Recent literature has revealed that extractive activity would be ideal for environmental sustainability but does not sustain families economically. Cattle have a strong market; however, it causes a high environmental impact. Subsistence agriculture presents productive diversity and market potential; however, impacts the environmental resources of the EXREs.

In the social area, the situation of education has proved unsustainable in the two EXREs, as they lack essential elements for operation and maintenance, such as the structure of schools and the presence of teachers and students. A similar situation is proven in the EXREs Canutama, Tapauá, Parest do Matupiri and Reserves of Sustainable Development of Igapó-Açu, where few vacancies are offered for elementary school, the existence of high school dropout and absence of teachers (COSTA et al., 2015). Despite the fact that the EXREs have consolidated themselves as a viable alternative to sustainable development policy in the Amazon, throughout its existence, it has shown unsatisfactory results (FREITAS et al., 2018). 
This phenomenon limits the development of traditional communities since it makes it difficult to achieve autonomy and improvement in the living conditions of each inhabitant. (PUTNAM, 1994). Therefore, the higher the educational level, the higher the economic growth (NOWAK; DAHAL, 2016; PASTOR et al., 2018). These arguments are not incompatible with the reality of EXREs because the state management model hinders access to school and motivates the migration of students to urban centres.

The health area goes in the same direction as education. It does not have the minimum for care and respect for human life. Recent studies maintain that this area suffers from precariousness, poor working conditions, scrapping and poor remuneration of professionals, which affects the system completely (ANDRADE; PEREIRA, 2020). They are deficiencies of the historical process loaded with inequalities and contradictions inherent in their own system (SILVA, 2019). The health system does not work at all in EXREs, because the lack/absence of physical structure and professionals is visible.

The study by Silva et al. (2015) in the EXREs Canutama, Tapauá, Sustainable Development Reserves of Matupiri, Madeira River, Igapó-Açu, Amapá River and Piagaçu-Purus demonstrated that these areas do not have access to drinking water services, minimum sewage treatment and adequate destination of solid waste. For this and other reasons, health policies for the population of the camp are still disjointed and disintegrated (MIRANDA et al., 2020). They reproduce the social inequalities, inequities and low access to essential health goods (DANTAS et al., 2020), which we observed in the peripheries of the urban environment of the medium and large cities.

The results of the research indicate that in both areas, the reality is not different from others with the same sustainability purposes of the Amazon. What is observed is the opposite, that is, social, economic and environmental unsustainability, given the low technological investment and vulnerable family-based project.

In turn, the extraction of chestnut, vegetable oils and rubber have the potential for supply in EXRE Rio Ouro Preto but continues to decline due to irrelevant investments and low competitiveness. Without significant financial support in the forms of subsidies and other development programs, the Non-Timber Forest Projects (NMPs) (rubber, chestnut and açaí) will continue to fight against the economy of extensive cattle ranching, in order to increase its adoption as a strategy of lower risk to income generation (LOPESA et al., 2019).

In this perspective, the creation of EXREs is not always a guarantee of conservation of natural resources (HOMMA, 2014), sometimes described by a scenario of injustice and social exclusion (BERNARDES et al., 2018), sometimes justified by territorial conflicts (BRITO; TRECCANI, 2019), sometimes based on low social organization and disarticulation of the agroextractive sector (RAMOS et al., 2015). The effects of these situations are economic reduction 
of production, smaller distribution of income and increase in poverty in EXREs (MACIEL et al., 2019).

Furthermore, the difficulties of technological innovations nodded as rubber and Brazil nuts (MACIEL et al., 2018), reveal a barrier to improving the living conditions of extractivist, strengthening and verticalizing these activities (SILVA; PARAENSE, 2019). The income obtained with açaí is higher than with both activities (TRINDADE; NUNES; FERNANDES, 2012; JARAMILLO-GIRALDO et al., 2017). One of the reasons is that the fruit of açaí can be obtained quickly through management or planting and presents high commercial value when compared to other extractive products. However, the management of native açaizais in lowland forest is not yet practised, nor the planting on land in the EXREs. Therefore, what is observed are productive technologies and financing for an extractive product of production scale, which has not yet been the object of action to sustainability policies.

Moreover, the perception of plants for medicinal purposes evidences the idea of natural resource and its phytomedicinal uses (SANTOS et al., 2020), as well as the rescue, valorization, experiences and popular knowledge generate autonomy for farmers (LIMA et al., 2020). Thus, natural resources and biodiversity have an important value of use and symbolic value, as they are not conceived as "commodities" (utilitarian logic), but aim, as a priority, at meeting social and local needs (DINIZ, 2019). Thus, the non-commercial extractivism of medicinal plants (cure of diseases) and the creation of animals (subsistence) is part of the customs, beliefs and values of the inhabitants.

For example, plants and herbs serve both to cure diseases and to prepare teas and constitute the culture of traditional communities of the EXREs. Furthermore, the hunting of wild animals, the production of redneck chicken meat, pigs, cattle, milk and eggs make up the types of products that have commercial value but are not marketed due to low production and low prices in EXREs. Again, the limitation of scale, lack of management technologies, planting and processing, and lack of studies to solve the problem become the main bottlenecks in these areas.

From another perspective, the sale of carbon credit appears as the protagonist (CASTELO, 2020), that is, the State's environmental policy has in the sale of environmental services and carbon credits the backbone of many proposals for the Amazon (HOMMA, 2020). These prioritize the conservation of primary areas and attach low importance to secondary areas. In practice, the priority to the standing forest and its resources is inversely proportional to possible sustainable projects in deforested areas that effectively improve the lives of the inhabitants.

In fact, there is a conflicting dichotomy between public policies of the national State and the way of life of EXRE communities, because when the State invests only in ecosystem conservation, the inhabitants seek means that enable subsistence, even if it is necessary to ignore the legal rules defined in the plan of use or management. This indicates difficulty for state institutions to respect 
organizational processes, needs and demands (CALEGARE; HIGUCHI, 2018), in order to meet social, economic and environmental requirements (KAUANO et al., 2020).

More specifically, EXREs have faced many obstacles in access to public policies of education, health, work (LIMA, 2020), economic decline and social inclusion (DANNER; DANNER; DORRICO, 2020). Public policies in the scientific and technological area (PCTIs) have to start to give innovation, mainly technological, in order to meet social objectives (issues involving well-being) and productive subsistence activities (MAZZETTI; GAZOLLA; MARINI, 2020). This impasse seems to indicate a lack of consensus and interests, in a way, harming the EXREs with deforestation, burning and ecosystem loss.

Given this reality, it is evident that it is necessary to rethink ways of survival of poor and excluded people who, without basic conditions of survival, often leave their homes, their history and migrate to cities in search of better living conditions (HADDAD; MADI; RABBIT, 2020). In these areas, it is strategic to plan Amazon conservation policies and, at the same time, develop economic projects (BARBOSA; MORET, 2015, p. 21), with the priority of the sustainability of the inhabitants (ARAÚJO, BERNARD, 2016) and/or provide essential conditions to life (SOARES; FONSECA FILHO, 2020). After three decades of implementing the EXREs model as a sustainability strategy, the Amazon remains vulnerable, productively isolated and with policies without synergistic connection necessary to environmental, economic and social sustainability.

\section{CONCLUSIONS}

Extractivism is the most appropriate productive model for forest conservation of EXREs, but it is not economically supported by itself, due to the limitation of scale, processing and low productivity of land, labour and income resulting from the extraction of these resources. Cattle raising and shifting cultivation, even with low productivity, emerges as a more viable economic and/or survival possibility, with limitations for the preservation of natural resources in the extensive form, due to the continuous incorporation of new areas. The ecology versus economics paradox still has limitations on sustainable balance. The policy of the last two decades prioritized environmental conservation and did not generate economic and technological alternatives for the main actors that can convert the current reality of unsustainability in the Amazon.

EXREs continue to be affected by little investment in education, health, productive extractivism activities and sustainable agriculture. The projects with greater visibility in these areas are aimed at the conservation of forest resources (fauna and flora), in addition to the sporadic policies of community-based tourism and small extractive practices. The "balance" side of sustainability still weighs considerably for natural protection. 
As much as forest resources are leveraged, there are needs for innovations, technologies and proper management in both primary and secondary areas of EXREs. These are essential policies that encourage the supply of extractive, agricultural and small animal products, which replace the crop of cutting and burning in these areas. In addition to determining a socio-environmental equilibrium point, it also eliminates conflicts between conservation and development by hastening the forest transition. The forest transition should occur with reduction or neutralization of deforestation with the increase of forestation and the conversion of the liabilities of Permanent Preservation Area (PPA) and Legal Reserve Area (LRA) and the increase in agricultural productivity.

To improve the reality of EXREs, some strategies are needed: offering an education and health structure that meet the basic needs of residents; technological subsidy to strengthen agroextractive production and expand market potential; insertion of technologies, improvements in transport conditions to ensure the expansion of markets for production; mills for processing and packaging cassava flour; plants for tobacco production; implementation of small structures for poultry farms, eggs, pigs and tanks for fish farming; agroforestry management plans of açaizeiro, cupuaçuzeiro, pupunheira and chestnut; incentives for the acquisition of fruit pulp processing machines; subsidized credit for family farming and cooperative organization.

The sustainability of the Amazon depends on both public policies and non-governmental partnerships that value environmental resources and the improvement in the living conditions of traditional forest inhabitants. Environmental investments must be thought, planned and connected with their social needs, or the State will continue to maintain livestock and agriculture with low productivity and the continuous incorporation of new areas of dense forest or secondary vegetation.

\section{REFERENCES}

ALLEGRETTI, M. H. Reservas Extrativistas: parâmetros para uma olítica de desenvolvimento sustentável na Amazônia. Revista Brasileira de Geografia, v. 54, p. 5-23, 1992.

ALLEGRETTI, M. H. Reservas Extrativistas: uma proposta de desenvolvimento para a floresta Amazônica. Fundação SEADE, v. 3, n. 4, p. 23-29, 1989.

AMARAL FILHO, O. Marca Amazônia: o marketing da floresta. 1. ed. Curitiba: Editora CRV, 2016. 256p.

AMIN, M. M. A Amazônia na geopolítica mundial dos recursos estratégicos do século XXI. Revista Crítica de Ciências Sociais, n. 107, p. 17-38, 2015.

ANAYA, F. C.; FELICIANO, P. H.; ESPIRITO SANTO, M. M. O território e os conflitos entre povos e comunidades tradicionais e unidades de conservação. In: COLÓQUIO INTERNACIONAL POVOS E COMUNIDADES TRADICIONAIS. 1., Montes Claros. Anais... Montes Claros, 2019. 
ANDRADE K. R. C. Tradução do conhecimento na realidade da saúde pública brasileira. Revista de Saúde Pública, v. 54, n. 72, p. 1-7, 2020.

ARAGÃO, A. L.; OLIVEIRA, K. S.; OLIVEIRA, P. T. C. Precarização do Trabalho na Saúde Pública e a Violência Obstétrica. In: CONGRESSO BRASILEIRO DE ASSISTENTES SOCIAIS. 16., 2019, Brasília. Anais... Brasília: CBAS, 2019. p. 26-29.

ARAGÓN, L. E. A dimensão internacional da Amazônia e os novos movimentos migratórios na região. Paper do NAEA, v. 28, n. 3, p. 185-198, 2020.

ARAGÓN, L. E. Migrações internacionais contemporâneas na Pan-Amazônia: avanços e desafios de pesquisa. Revista Latino-Americana de Estudos Avançados, v. 2, n. 1, p. 96-116, 2017.

ARAÚJO, J. L.; BERNARD, E. Management effectiveness of a large marine protected area in Northeastern Brazil. Ocean \& Coastal Management, v. 130, p. 43-49, 2016.

BARBOSA, A.; MORET, A. Produção e comercialização da castanha do Brasil: economia e disponibilidade financeira (subsistência das famílias residentes em reservas extrativistas). Revista de Gestão Sustentável Ambiental, v. 4, n. 2, p. 413-428, 2015.

BERESFORD, A. E.; ESHIAMWATA, G. W.; DONALD, P. F.; BALMFORD, A.; BERTZKY, B..; BRINK, A. B.; FISHPOOL, L. D. C.; MAYAUX, P.; PHALAN, B.; SIMONETTI, D.; BUCHANAN, G. M. Protection Reduces Loss of Natural Land-Cover at Sites of Conservation Importance across Africa. PLoS ONE, v. 8, n. 5, p. 31-46, 2013.

BERNARDES, R. S.; COSTA, A. D.; BERNARDES, C. Projeto sanear Amazônia: tecnologias sociais e protagonismo das comunidades mudam qualidade de vida nas reservas extrativistas. Desenvolvimento e Meio Ambiente, v. 48, p. 263-280, 2018.

BLANCO-GUTIÉRREZ, I.; MANNERS, R.; VARELA-ORTEGA， C.; TARQUIS, A. M.; MARTORANO, L. G.; TOLEDO, M. Examining the sustainability and development challenge in agricultural-forest frontiers of the Amazon Basin through the eyes of locals. Natural Hazards and Earth System Sciences, v. 20, p. 797-813, 2020.

BRASIL. Constituição da República Federativa do Brasil de 1988. Art. 196, Subchefia para Assuntos Jurídicos. Brasília, 22 de set. 1988. Avaiable at: http://www.mpgo.mp.br/portal/system/resources. Access on: 8 sep. 2020.

BRASIL. Decreto $\mathbf{n}^{\mathbf{0}}$ 98.863. Criação da Reserva Extrativista do Alto Juruá. Diário Oficial da República Federativa do Brasil. Brasília, Subchefia para Assuntos Jurídicos, 23 de jan. 1990. Avaiable at: https://www2.camara.leg.br/legin/fed/decret/1990. Access on: 8 sep. 2020.

BRASIL. Decreto n 99.166. Criação da Reserva Extrativista Rio Cajari. Diário Oficial da República Federativa do Brasil, Brasília, Subchefia para Assuntos Jurídicos, 13 de mar. 1990, p. 1-4. Avaiable at: https://www2.camara.leg.br/legin/fed/decret/1990/decreto-99166-13-marco-1990. Access on: 8 sep. 2020.

BRASIL. INSTITUTO BRASILEIRO DE GEOGRAFIA E ESTATÍSTICA. Censo Demográfico
2010. $\quad$ Brasília: http://ww2.ibge.gov.br/home/estatistica/populacao/censo2010/.shtm. Acecess on: 8 sep. 2020. 
BRASIL. INSTITUTO CHOCO MENDES DE CONSERVAÇÃO DA BIODIVERSIDADE. Unidades de Conservação na Amazônia. Ministério do Meio Ambiente, 20 de set. 2020. [accessed on 2020 Sep. 8]. Avaible at: https://www.icmbio.gov.br/portal/unidadesdeconservacao/biomasrasileiros/amazonia/unidades-de-conservacao-amazonia/2776-resex-alto-jurua. Access on: 8 sep. 2020.

BRITO, S. V.; TRECCANI, G. D. Unidades de Conservação na Amazônia e territorialidades específicas: o caso da Reserva Extrativista de Ipaú-Anilzinho. Revista de Direito e Sustentabilidade, v. 5, n. 2, p. 95-113, 2019.

CAlEGARE, M. G. A.; HIGUCHI, M. I. G. Participatory action research in an Amazon Protected Area: lessons for community psychology in Northern Brazil. Journal of Comunity \& Applied Social Psychology, v. 28, n. 3, p. 1-12, 2018.

CANTO, O.; SOBRINHO, M. V.; VASCONCELLOS, A. M. A.; FERREIRA, L. R.; BARETTA, A. I._Conflitos socioambientais e limites da gestão compartilhada em Unidade de Conservação na zona costeira amazônica. Redes, v. 25, p. 1528-1552, 2020.

CASTELO, C. E. F. Um olhar sobre o desenvolvimento acreano: a florestania e outras histórias. Revista Nera, v. 23, n. 51, p. 117-132, 2020.

CAVAlCANTI, F. C. S.; BATISTA, G. E. A.; SOUZA, E. F. As Unidades de Conservação e a questão do desmatamento no Acre: o papel da Resex Chico Mendes. In: CONGRESSO BRASILEIRO DE ADMINISTRAÇÃO, ECONOMIA E SOCIOLOGIA RURAL. 56., 2018, Campinas. Proceedings... Campinas, 2018.

COSTA, M.; FRAXE, T.; SANTIAGO, J.; VASQUES, M. A Educação Escolar nas Unidades de Conservação: entre os desafios e possibilidades de processos educativos diferenciados. In: PEREIRA, H.; FRAXE, T.; COSTA, F.; WITKOSKI, A. (Org.). Unidades de Conservação do Amazonas no Interflúvio Purus-Madeira: diversidade cultural e gestão social dos bens comuns. Manaus: EDUA, 2015. p. 86-117.

DANNER, L. F.; DANNER, F.; DORRICO, J. A Lenta agonia da Amazônia brasileira: abandono político, subdesenvolvimento econômico, destruição ambiental e etnocídio cultural. Revista Labirinto, v. 31, n. 19, p. 80-96, 2020.

DANTAS, C. M. B.; DIMESNTEIN, M.; LEITE, J. F.; MACEDO, J. P.; BELARMINO, V. H. Território e determinação social da saúde mental em contextos rurais: cuidado integral às populações do campo. Athenea Digital, v. 20, n. 1, p. 1-21, 2020.

DINIZ, R. F. Etnosaberes e culturas tradicionais afrobrasileiras: farmacopeia, magia e reprodução material e simbólica de comunidades quilombolas do vale do Jequitinhonha-MG. GEOgraphia, Niteroi, v. 21, n. 47, p. 13-24, 2019.

DIZDAROGLU, D. The role of indicator-based sustainability assessment in policy and the decisionmaking process: a review and outlook. Sustainability, v. 9, n. 6, p. 1-28, 2017.

FREITAS, J. S.; FARIAS FILHO, M. C.; HOMMA, A. K. O.; MATHIS, A. The unsustainability of Extractive Reserves in the Amazon: socio-economic demands versus environmental conservation. Desenvolve: Revista de Gestão da Unilasalle, v. 9, n. 1, p. 9-27, 2020. 
FREITAS, J. S.; FARIAS FILHO, M. C.; HOMMA, O. K. A. MATHIS, A. Reserva extrativista sem extrativismo: uma tendência em curso na Amazônia? Revista de Gestão Social e Ambiental, v. 12, n. 1, p. 56-72, 2018.

FREITAS, J. S.; MATHIS, A.; FARIAS FILHO, M. C.; HOMMA, A. K. O.; SILVA, D. C. Reservas Extrativistas na Amazônia: modelo de conservação ambiental e desenvolvimento social? GEOgraphia, Niterói, v. 19, n. 40, p. 150-160, 2017.

GUIMBERTEAU, M.; CIAIS, P.; DUCHARNE, A.; BOISIER, J. P.; DUTRA AGUIAR, A. P.; BIEMANS, H.; DEURWAERDER, H.; GALBRAITH, D; KRUIJT, B.; LANGERWISCH, F.; POVEDA, G.; RAMMIG, A.; RODRIGUEZ, D. A.; TEJADA, G.; THONICKE, K.; VON RANDOW, C.; VON RANDOW, R. C. S.; ZHANG, K.; VERBEECK, H. Impacts of future deforestation and climate change on the hydrology of the Amazon Basin: a multi-model analysis with a new set of landcover change scenarios. Hydrology an Earth System Sciences, v. 21, p. 1455$1475,2017$.

HADDAD, R. D.; MADI, R. R.; COELHO, A. S. Lifestyles of populations of Extractive Reserves of Rondônia - Brazil. International Journal of Social Science Studies, v. 8, n. 1, p. 8-17, 2020.

HOMMA, A. K. O. Amazônia: a civilização do fogo. In: ALVES, R. N. B.; MODESTO JÚNIOR, M. S. Roça sem Fogo: da tradição das queimadas à agricultura sustentável na Amazônia. Brasília: EMBRAPA, 2020. p. 11-33.

HOMMA, O. K. A. Extrativismo Vegetal na Amazônia: história, ecologia, economia e domesticação. Brasília: EMBRAPA, 2014. 468p.

IORIS, A. R. Socioecological economics of water development in the Brazilian Amazon: elements for a critical reflection. Ecological Economics, v. 173, n. 106654, p. 1-6, 2020.

JARAMILLO-GIRALDO, C.; SOARES- FILHO, B.; RIBEIRO, C. M. S.; GONÇALVES, C. R. Is it possible to make rubber extraction ecologically and economically viable in the Amazon? The southern Acre and Chico Mendes Reserve case study. Ecological Economics, v. 134, p. 186-197, 2017.

KAUANO, E.; SILVA, J. M. C.; DINIZ FILHO, J. A. F.; MICHALSKI, F. Do protected areas hamper economic development of the Amazon region? An analysis of the relationship between protected areas and the economic growth of Brazilian Amazon municipalities. Land Use Policy, v. 92, n. 104473, p. 1-12, 2020.

KLIMAS, C. A.; CROPEER Jr., W. P.; KAINER, K. A.; WADT, L. H. O. Viability of combined timber and non-timber harvests for one species: a carapa guianensis case study. Ecological Modelling, v. 246, p. 147-156, 2012.

KRÖGER, M. Deforestation, cattle capitalism and neodevelopmentalism in the Chico Mendes Extractive Reserve, Brazil. The Journal of Peasant Studies, v. 43, n. 3, p. 464-482, 2019.

LIMA, J. F.; NETO, J. G. O.; ARAÚJO, A. E.; SILVA, D. A.; FREITAS, J. T. Levantamento participativo e formação continuada sobre plantas medicinais cultivadas no município de Serraria-pb. Brazilian Journal of Agroecology and Sustainability, v. 3, p. 1-17, 2020.

LIMA, R. Notas sobre as políticas públicas para as mulheres no Estado do Amazonas. Revista Artigos.com, v. 15, p. 1-11, 2020. 
LOPESA, E.; SOARES-FILHO, B.; SOUZA, F.; RAJÃO, R.; MERRY, F.; CARVALHO RIBEIRO, S. Mapping the socio-ecology of non timber forest products (NTFP) extractionin the Brazilian Amazon: the case of açaí (Euterpe precatoriaMart) in Acre. Landscape and Urban Planning, v. 188, p. 110-117, 2019.

MACIEL, R. C. G.; ALMEIDA, A. M.; MENEZES, H. C. S. Avaliação econômica da pecuária de gado na Reserva Extrativista Chico Mendes. In: In: CONGRESSO BRASILEIRO DE ADMINISTRAÇÃO, ECONOMIA E SOCIOLOGIA RURAL. 56., 2018, Campinas. Proceedings... Campinas, 2018.

MACIEL, R. C. G.; CAVALCANTE FILHO, P. G.; ARAÚJO, W. S. A.; OLIVEIRA, O. F. Pobreza, segurança alimentar e autoconsumo na Reserva Extrativista (RESEX) Chico Mendes. In: CONGRESSO BRASILEIRO DE ADMINISTRAÇÃO, ECONOMIA E SOCIOLOGIA RURAL. 56., 2018, Campinas. Proceedings... Campinas, 2018.

MACIEL, R. C. G.; CAVAlCANTE FILHO, P. G.; RIBEIRO, L. N.; SILVA, G. S. A. L. Distribuição de Renda e Pobreza na Reserva Extrativista (RESEX) Chico Mendes. In: CONGRESSO BRASILEIRO DE ADMINISTRAÇÃO, ECONOMIA E SOCIOLOGIA RURAL. 56., 2018, Campinas. Proceedings... Campinas, 2018.

MACIEL, R.; REYDON, B.; COSTA, J.; SALES, G. Pagando pelos serviços ambientais: uma proposta para a Reserva Extrativista Chico Mendes. Acta Amazônia, v. 40, n. 3, p. 489-498, 2010.

MAZZETTI, A. C.; GAZOLLA; M.; MARINI, M J. PCTI no Brasil: a relação inovação e sistema produtivo na atual estratégia nacional. Revista do Desenvolvimento Regional, v. 17, n. 1, p. 105$120,2020$.

MENEZES, T. C. Environmental governance and regularization of land ownership: development and multiple territorial dynamics in the Amazon. Virtual Brazilian Anthropology, v. 17, p. 1-18, 2020.

MIRANDA, S. V. C.; OLIVEIRA, P. S. D.; MORAES, V. C. M.; VASCONCELLOS, L. C. F. Necessidades e reivindicações de homens trabalhadores rurais frente à atenção primária à saúde. Trabalho Educação e Saúde, v. 18, n. 1, p. 1-22, 2020

NOGUEIRA, E. M.; YANAI, A. M.; VASCONCELOS, S. S.; GRAÇA, L. M. P. A.; FEARNSIDE, P. M. Carbon stocks and losses to deforestation in protected areas in Brazilian Amazonia. Regional Environmental Change, v. 18, p. 261-270, 2018.

NOWAK, A. Z.; DAHAL, G. 2016. The contribution of education to economic growth: evidence from Nepal. International Journal of Economic Sciences, v. 2, p. 22-41, 2016.

PASTOR, J. M.; PERAITA, C.; SERRANO, L.; SOLER, Á. Higher education institutions, economic growth and GDP per capita in European Union Countries. European Planning Studies. v. 26, p. 1616-1637, 2018.

PRETTY, J. Agricultural sustainability: concepts, principles and evidence. philosophical transactions of the royal society. Biological Sciences, v. 363, n. 1491, p. 447-465, 2008.

PUTNAM, R. D. Social capital and public affairs. Bulletin of the American Academy of Arts and Sciences, v. 47, n. 8, p. 5-19, 1994. 
RAMOS, A.; FRAXE, T.; WITKOSKI, A.; CASTRO, A.; COSTA, F. Aspectos da organização social em unidades de conservação do Amazonas. In: PEREIRA, H.; FRAXE, T.; COSTA, F.; WITKOSKI, A. (Org.). Unidades de Conservação do Amazonas no Interflúvio Purus-Madeira: diversidade cultural e gestão social dos bens comuns. Manaus: EDUA, 2015, p. 151-169.

RIBEIRO, Y. M.; GUSMÃO, J. B. Indicadores da Qualidade na Educação. 4. ed. São Paulo: Ação Educativa, 2004. 61p.

SANTOS, F. S.; SANTOS, J. S.; COSTA, L. A. F.; SILVA, W. S.; OLIVEIRA, M. F. Prefiro plantas do que remédios": o uso de plantas para fins medicinais no território quilombola cajá dos negros, em Batalha-Alagoas. Diversitas Journal, v. 5, n. 1, p. 235-248, 2020.

SILVA, A. S. O; PARAENSE, V. C. Production chain for Brazil-Nuts (Bertholletia excelsa Bonpl.) at Ipaú-Anilzinho Extractive Reserve, Municipality of Baião., Pará, Amazonian Brazil. Revista Agro@mbiente, v. 13, p. 68-80, 2019.

SILVA, C.; FRAXE, T.; SILVA, M. Potencial arqueológico do Baixo Rio Purus/AM: um estudo preliminar. In: PEREIRA, H.; FRAXE, T.; COSTA, F.; WITKOSKI, A. (Org.). Unidades de Conservação do Amazonas no Interflúvio Purus-Madeira: diversidade cultural e gestão social dos bens comuns. Manaus: EDUA, 2015, p. 171-186.

SILVA, M.; VASCONCELOS, A.; FRAXE, T.; ANDRADE, J. Saneamento Ambiental das Unidades de Conservação Estaduais do Amazonas na Área de Influência da BR-319. In: PEREIRA, H.; FRAXE, T.; COSTA, F.; WITKOSKI, A. (Org.). Unidades de Conservação do Amazonas no Interflúvio Purus-Madeira: diversidade cultural e gestão social dos bens comuns. Manaus: EDUA, 2015. p. 52-84.

SILVA, P. L. M. Informalidade e Saúde Pública: reflexos da privatização e precarização. In: ENCONTRO INTERNACIONAL DE POLÍTICA SOCIAL. 7., 2019, Vitória. Proceedings... Vitória: ENPS, 2019. p. 1-14.

SIVIERO, A.; TEIXEIRA, P. E. F.; SANTOS, R. C. A produção agropecuária nas Reservas Extrativistas do Acre. In: SIVIERO, A.; SANTOS, R. C.; MATTAR, E. P. L. Conservação e tecnologias para o desenvolvimento agrícola e florestal do Acre. Rio Branco: IFAC, 2019, p. 337378.

SOARES, J. B.; FONSECA FILHO, R. E. Diferentes olhares do turismo de base comunitária da Reserva Extrativista Marinha de Soure, Amazônia. Revista Brasileira de Ecoturismo, v. 13, n. 1, p. 155-157, 2020.

SONG, X.; HUANG, X.; FU, J.; JIANG, D.; TIAN, G. Spatial variability and ecological effects of anthropogenic activities in a nature reserve: a case study in the Baijitan National Nature Reserve, China. Sustainability, v. 9, n. 2, p. 1-14, 2017.

SPÍNOLA, J. N. Criação de gado em reservas extrativistas: ameaça ou necessidade? O caso da Reserva Extrativista Tapajós Arapiuns, Pará, Brasil. Desenvolvimento e Meio Ambiente, v, 51, p. 224-246, 2019.

TRINDADE, S. L.; NUNES, P. O.; FERNANDES, K. G. Avaliação da distribuição de cobre associado a compostos de diferentes massas moleculares na polpa de açaí. Acta Amazonica, v. 42, n. 2, p. 287-292, 2012. 
WALTER, M.; TOMÁS, S. L.; MUNDA, G.; LARREA, C. A social multi-criteria evaluation approach to assess extractive and non-extractive scenarios in Ecuador: Intag case study. Land Use Policy, v, 57, p. 444-458, 2016.

WEISSE, M.; NAUGHTON-TREVESWEISSE, L. Conservation beyond park boundaries: the impact of buffer zones on deforestation and mining concessions in the Peruvian Amazon. Environmental Management, v. 58, p. 297-311, 2016.

Trabalho enviado em $02 / 11 / 2020$ Trabalho aceito em 30/01/21 